\title{
Fracture of the temporal bone in patients with traumatic brain injury
}

\section{Fratura de osso temporal em pacientes com traumatismo crânio-encefálico}

\author{
Myrian Marajó Dal Secchi', Juliana Furno Simões Moraes², Fabrício Barbosa de Castro². \\ 1) Specialist Title in Otorhinolaryngology. Postgraduate Student Master`́s Degree Level of Otorhinolaryngology Discipline of College of Medical Sciences of São Paulo \\ Santa Casa. Chief Service of Otorhynolaringology of Brotherhood of Santa Casa of Mercy of Santos. \\ 2) Doctor. Trainee in Otorhynolaringology Service of Brotherhood of Santa Casa of Mercy of Santos. \\ Institution: Brotherhood of Santa Casa of Mercy of Santos. \\ Santos / SP - Brazil. \\ Mailing address: Myrian Marajó Dal Secchi - 254, Ana Costa, Av - Conj. 72 - Santos / SP - Brazil - Zip code: 11060-000 - Telephone (+55 13) $3234-7736$ - E- mail: \\ dalsecchi@uol.com.br. \\ Article received in 2011 June $09^{\text {th }}$. Article approved in 2011 September $19^{\text {th }}$
}

\section{SUMMARY}

Introduction: The fractures in the temporal bone are lesions that are observed in patients with traumatic brain injury (TBI). The computed tomography of high-resolution (CT) allows evaluating the fracture and the complications.

Objective: Evaluate patients with TBI and temporal bone fracture.

Way of study: Retrospective study.

Method: Were evaluated 28 patients interned by TBI with clinical evidence and/or radiologic from temporal bone fractures.

Results: The age ranged from 3 to 75 years. The most affected side was the right side $50 \%(n=14)$, left side $36 \%(n=10)$ and both sides $14 \%(n=4)$. The etiology of the trauma was the falling $25 \%(n=7)$, accidents with motorcycles and bicycles $21 \%(n=6)$, physical aggression $14 \%(n=4)$, running over $11 \%(n=3)$, fall of object $4 \%(n=1)$ and other causes $25 \%(n=7)$. The clinical signs were: Otorrhagia $78 \%$, otalgia $11 \%(n=3)$, otorrhea $7 \%$ $(n=2)$, facial paralysis $7 \%(n=2)$ and hearing loss $7 \%(n=2)$. The otoscopic findings: otorrhagia $57 \%(n=16)$, laceration of external auditory canal 36\% ( $n=10)$, hemotympanum $11 \%(n=3)$, normal 7\% (n=2) and Battle signal 7\% (n=2). The findings for CT of skull were: with no alterations $54 \%(n=15)$ and temporal fracture $7 \%(n=2)$ and the CT of temporal bones were: line of fracture $71 \%(n=20)$, opacification of the mastoid $25 \%(n=7)$, glenoid cavity air $14 \%(n=1)$, dislocation of the ossicular chain $7 \%(n=2)$ and veiling of the middle ear $4 \%(n=1)$.

Conclusion: Patients with TBI must be submitted to the otorhinolaryngological evaluation and imaging, for the early diagnosis of the complications and treatment.

Keywords: temporal bone, fracture in the base of skull, computed tomography by X-ray.

\section{RESUMO}

Introdução: As fraturas de osso temporal são lesões que se observam em pacientes com traumatismo crânio-encefálico (TCE).A tomografia computadorizada de alta resolução (TC) permite avaliar a fratura e as complicações.

Objetivo: Avaliar pacientes com TCE e fratura de osso temporal.

Forma de estudo: Estudo retrospectivo.

Método: Foram avaliados 28 pacientes internados por TCE com evidência clínica e/ou radiológica de fratura de osso temporal.

Resultados: A faixa etária variou 3 a 75 anos O lado mais afetado foi o direito 50\% ( $n=14)$, esquerdo $36 \%(n=10)$ e bilateral 14\% (n=4). A etiologia do trauma foi queda $25 \%(n=7)$, acidentes com motocicletas e bicicletas 21\% $(n=6)$, agressão física $14 \%(n=4)$, atropelamento $11 \%(n=3)$, queda de objeto $4 \%(n=1)$ e outras causas $25 \%(n=7)$. Os sinais clínicos foram: otorragia $78 \%(n=22)$, otalgia $11 \%(n=3)$, otorreia $7 \%(n=2)$, paralisia facial $7 \%(n=2)$ e hipoacusia $7 \%(n=2)$. Os achados a otoscopia: otorragia 57\% $(n=16)$, laceração de conduto auditivo externo 36\% ( $n=10)$, hemotímpano $11 \%(n=3)$, normal $7 \%(n=2)$ e sinal de Battle $7 \%(n=2)$. Os achados à TC de crânio foram: sem alterações $54 \%(n=15)$ e fratura de temporal $7 \%(n=2)$ e na TC de ossos temporais foram: linha de fratura $71 \%(n=20)$, velamento da mastoide $25 \%(n=7)$, ar em cavidade glenóidea 14\% (n=4), luxação de cadeia ossicular 7\% $(n=2)$ e velamento orelha média $4 \%(n=1)$.

Conclusão: Pacientes com TCE devem ser submetidos à avaliação otorrinolaringológica e de imagem, para diagnóstico precoce das complicações e tratamento.

Palavras-chave: osso temporal, fratura da base do crânio, tomografia computadorizada por raios $\mathrm{X}$. 


\section{INTRODUCTION}

The temporal bone trauma is frequently associated to severe traumatic brain injury. Approximately $4 \%$ of the patients with head injury present fracture, and 14-22\% of these patients with fracture of temporal bone (1-2-3). The three causes more frequents are accidents with vehicles and motorcycles $45 \%$, falls $31 \%$, and robberies 11\% (1-6-9-10). The complications with fracture of temporal bone as hearing loss, facial paralysis and otogenic cerebrospinal fluid leak are evaluated by otorhinolaryngologist during hospitalization; the immediate care is performed by emergency team of trauma neurosurgery (1-2-3-5).

The precocious diagnosis is important for treatment of complications, the petrous portion of temporal bone contains the structures of middle ear, inner, the seventh and eighth cranial nerves, which are vulnerable to trauma when occurs the bone fracture. The top floor of the middle fossa to the region of middle ear and mastoid, the tegmen tympani, Isa thin bone, and its disruption can produce a fistula in the hard, with leakage of cerebrospinal liquor to the ear, with otorrhea and rhinorrhea via the Eustachian tube, if the tympanic membrane is intact (3-5-6). Some of greater complications associated to the fracture of temporal bone are sensorineural hearing loss and conductive, cerebral ischemia, and facial paralysis, less common paralysis of the abducens and trigeminal nerve, and sigmoid sinus thrombosis.

The clinical signs of trauma in temporal bone include: fracture along the roof of the external auditory canal, rupture of the tympanic membrane with otorrhea and otorrhagia, hemotympanum, cerebrospinal fluid leak, hearing loss, facial paralysis, Battle's sign (bruising of the mastoid tip). The fractures of temporal bone occur in traumas with force approximated of $1,875 \mathrm{lb}$, and frequently are patients with polytrauma.

At evaluation of these patients in emergency is performed computerized tomography (CT) of skull, the absence of fracture trace does not exclude it in patients with clinical signs with fracture of temporal bone, and it should be investigated with otoscopy, functional assessment seventh and eighth pair and temporal bone CT (3-8-10). The radiological sings in CT skull opacification of the mastoid cells, or middle ear, pneumocephalus near the temporal area, air in the glenoid cavity are suggestive of temporal bone fracture, which may be confirmed with CT temporal bone in high (3-4-5-9). With CT of temporal bones in high resolution there is better definition of line of the fracture and extension, or visualization when it is hidden like in cases of opacification of mastoid cells pneumocephalus, evaluation of impairment of carotid canal and ossicles (2-7-8).

The fractures of temporal bone are classified when parallel to the petrous pyramid in longitudinal, and transverse and perpendicular. However the clinical evaluation is more important in classification of fractures than radiological traces. A new classification is based on impairment or not of otic capsule, being important these information to the prognostic of these patients. The trauma force must be intense to reach the otic capsule, and result in serious sequelae with sensorineural hearing loss, paralysis including intracranial complications. The patients with skull injury must be submitted to evaluation of clinical otorhinolaryngological, functional and of image, it is important the integration among the emergency team, neurosurgeons and radiologists to precocious diagnosis and treatment of complications (4-9).

The study objective is to evaluate the patients with traumatic brain injury who presented clinical evidence and/ or radiological fracture of temporal bone.

\section{METHOD}

Retrospective study in inpatients by traumatic brain injury (TBI) from January 2007 to January 2010. Data were collected from medical reports of inpatients of 1997with TBI diagnosis, from these 442 (22\%) presented severe TBI, with 67 deaths (15\%) and 59 (13\%) with suggestive clinical signs of temporal bone trauma. From 59 (13\%) patients, 28 (47\%) presented the criteria inclusion of this study.

Inclusion criteria: inpatients by traumatic brain injury which presented clinical evidence and/ or radiological (skull CT) of temporal bone fracture submitted to otorhinolaryngological evaluation and CT of temporal bones. Criteria exclusion: patients of traumatic brain injury who were not submitted to CT of temporal bones due to trauma severity, without clinical conditions to examination. We analyzed in 28 patients, the more frequent clinical signs, age group, trauma etiology and the findings of CT of skull and temporal bones.

Approved by the Ethics and Research Committee of Brotherhood of Santa Casa of Mercy of Santos number 26/2010.

\section{RESULTS}

For 28 patients of this study was requested the otorhinolaryngological evaluation by presented clinical 
signs of temporal bone injury. Being 20 of masculine gender and 8 of feminine, the age group varied from 3 to 75 years ( $14 \pm 19$, average \pm DP), prevalent among 21-30 year (28\%) Table 1 . The side more affected was the right 50\% ( $n=14)$, left 36\% $(n=10)$ and bilateral 14\% $(n=4)$. The trauma etiology was accidents with fall $25 \%$, motorcycles and bicycles $21 \%(n=6)$, physical aggression $14 \%(n=4)$, running over $11 \%(n=3)$, falling object $4 \%(n=1)$ and other causes $25 \%(n=7)$, there were not any case of injury by fire gun Table 2. The clinical signs were: otorrhagia $78 \%$ $(n=22)$, otalgia $11 \%(n=3)$, otorrhea $7 \%(n=2)$, facial paralysis $7 \%(n=2)$, hearing loss 7\% $(n=2)$ Table 3. Otoscopy findings: otorrhagia $57 \%(n=16)$, laceration of external auditory canal $36 \%(n=10)$, hemotympanum $11 \%(n=3)$, normal 7\% $(\mathrm{n}=2)$ and Battle's sign (retroauricular hematoma associated with hemotympanum) $7 \%(\mathrm{n}=2)$.

Skull CT findings were: without changes $54 \%(n=15)$, subgaleal hematoma $18 \%(n=5)$, blood collection in the maxillary sinus $14 \%(n=4)$, subarachnoid hemorrhage $14 \%$ $(n=4)$, pneumocephalus $11 \%(n=3)$, extradural hematoma $4 \%(n=1)$ e subdural $4 \%(n=1)$, frontal fracture $7 \%(n=2)$, temporal $7 \%(n=2)$, parietal $4 \%(n=1)$, occipital $4 \%(n=1)$ and zygomatic $4 \%(n=1)$ and temporal bones high resolution CT and the changes found were: line of fracture $71 \%$ $(n=20)$, mastoid opacification $25 \%(n=7)$, air in glenoid cavity $14 \%(n=4)$, luxation of ossicular chain $7 \%(n=2)$ and middle ear opacification $4 \%(n=1)$. Table 4 . From 28 patients submitted to temporal bones $\mathrm{CT}$, the fracture line was found in CT of 20 patients being longitudinal in 64\% $(n=18)$ and transverse $7 \%(n=2)$.

\section{DISCUSSION}

The temporal bone fractures are lesions which are observed in patients who suffered traumatic brain injury (TBI), it occurs in 5 to $10 \%$ of head injuries, with modern image techniques, as high resolution CT, in some series can reach $20-40 \%$ (1-10).

In our study, patients with temporal bones involvement was of $13 \%(n=59)$, from these $47 \%(n=28)$ were submitted to high resolution CT of temporal bones and the fracture line was viewed in $71 \%(n=20)$ of cases, from these $7 \%(n=2)$ was visible on CT scan. In one third of the temporal bone fractures is not evident in CT of cranial anterior, the high resolution of temporal bones present an excellent sensitivity to these fractures. (1-7). The absence of visible fracture in skull CT does not exclude it, and those patients with clinical signs of fracture must have an adequate treatment and to be investigated (3).

The temporal bone clinical sign of trauma along the roof of the external auditory canal, tympanic membrane
Table I. Patients distribution by age group and gender.

\begin{tabular}{lcccc}
\hline Age & Masculine & Feminine & $n$ & $\%$ \\
\hline $0-10$ & 3 & 2 & 5 & $19 \%$ \\
$11-20$ & 2 & 2 & 4 & $14 \%$ \\
$21-30$ & 5 & 3 & 8 & $28 \%$ \\
$31-40$ & 4 & 0 & 4 & $14 \%$ \\
$41-50$ & 2 & 0 & 2 & $7 \%$ \\
$51-60$ & 2 & 1 & 3 & $11 \%$ \\
$6 \mid-75$ & 2 & 0 & 2 & $7 \%$ \\
\hline Total & 20 & 8 & 28 & $100 \%$ \\
\hline
\end{tabular}

Table 2. Etiology of temporal bones fracture.

\begin{tabular}{lcc}
\hline & $\mathrm{n}$ & $\%$ \\
\hline Fallings & 7 & $25 \%$ \\
Motorcycleaccident & 4 & $14 \%$ \\
Physicalaggression & 4 & $14 \%$ \\
Runningover & 3 & $11 \%$ \\
Bicycleaccident & 2 & $7 \%$ \\
Fallingobjects & 1 & $4 \%$ \\
Othercauses & 7 & $25 \%$ \\
\hline Total & 28 & $100 \%$ \\
\hline
\end{tabular}

Table 3. Temporal boné trauma: clinical sings.

\begin{tabular}{lcc}
\hline Clinical signs & $\mathrm{n}$ & $\%$ \\
\hline Otorrhagia & 22 & $78 \%$ \\
Otalgia & 3 & $11 \%$ \\
Facial Paralisys & 2 & $7 \%$ \\
HearingLoss & 2 & $7 \%$ \\
Otorrhea & 2 & $7 \%$ \\
\hline
\end{tabular}

Table 4. Findings in high resolution computerized tomography of temporal bones.

\begin{tabular}{lcc}
\hline & $\mathrm{n}$ & $\%$ \\
\hline Fracture line & 20 & 71 \\
Mastoid opacification & 7 & 25 \\
Airinglenoid cavity & 4 & 15 \\
Ossicularchain luxation & 2 & 7 \\
Middleearopacification & 1 & 4 \\
\hline
\end{tabular}

ruptures with otorrhea, otorrhagia, hemotympanum and hematoma at the tip of the mastoid (Battle's sign). The complications are sensorineural hearing loss and / or conductive, perilymphatic fistula and cerebrospinal fluid and facial paralisys (1-4-7-6-9-10). In study, the main clinical signal was otorrhagia in $78 \%(n=22)$ of the cases, the other signs were: otalgia $11 \%(n=3)$, otorrhea $7 \%(n=2)$, facial paralisys $7 \%(\mathrm{n}=2)$ and hearing loss $7 \%(\mathrm{n}=2)$. The 
most frequent findings of otoscopy were: otorrhagia 57\% $(\mathrm{n}=16)$, followed by external auditory canal laceration36\% $(n=10)$, hemotympanum 11\% $(n=3)$ e Battle's sign (retroauricular hematoma associated to hemotympanum) $7 \%(n=2)$. Our results were similar to Plaza Maior et al (10) who observed otorrhagia in $70,45 \%$ of cases and also it was found more frequent the otoscopy $(38,64 \%)$, and other clinical signs were hearing loss and facial paralisys and the otoscopy was hemotympanum.

In our patients who presented facial paralisys, occurred after trauma, with spontaneous recovery and without surgical indication, similar to the studies of Bordie et al, that in $73 \%$ of cases occurred after initial trauma, with spontaneous recovery. SARAHYA et al (1), reported that in major cases of facial paralisys are late to the trauma, and the decompressure of facial nerve is indicated in immediate cases and in late which does not present good evolution.

However the resolution of skull CT be inappropriate for temporal fracture diagnosis, it provides lesion evidences, when there's opacification or close to it, local pneumocephalus, sphenoid sinus opacification, air in the glenoid cavity (2-4-7-8). The findings which showed in the present study impairment of temporal bone in skull CT were: blood collection in the maxillary sinus $14 \%(n=4)$, pneumocephalus 11\% (n=3), temporal fracture $7 \%(n=2)$. While in high resolution CT of temporal bones of 28 patients, it was visualized line fracture in 20 cases, being 64\% $(\mathrm{n}=18)$ longitudinal and $7 \%(\mathrm{n}=2)$ transverse, other findings were: opacification of mastoid $25 \%(n=7)$, air in glenoid cavity $14 \%(n=4)$, ossicular chains luxation $7 \%$ $(n=2)$ and middle ear opacification $4 \%(n=1)$. Comparing the findings in skull and temporal bones CT, our results were in agreement with literature (1-3-7). The high resolution CT of temporal bones provides the line fracture definition and its extension of ossicular chain, carotid canal and geniculate ganglion (2).

The cause more frequent of temporal bone traumas are traffic accidents $45 \%$, fallings $31 \%$ and robberies $11 \%$ (1-5-6-9-10). In the study, we found falling in 25\% $(n=7)$ of cases, the motorcycles accidents and bicycles $21 \%(\mathrm{n}=$ 6) and other causes $25 \%(n=7)$, there were no case of injury with fire gun.

The temporal fractures are found relatively same in both sides, bilateral occur in $10-15 \%$ of patients, the average age is 41 years, and 22\% under 17 years, and 81\% occurred in masculine gender. In the study, the results were similar to the literature (1), with predominance of masculine gender in $71,4 \%(n=20)$ of cases and in $28,6 \%$ $(n=8)$ of feminine gender, the age group varied from 3 to 75 years, prevalent between 21-30 years. Related to the side, in study the right was more affected, the fracture was visualized in 50\% ( $n=14)$, in the left side occurred in 36\% $(n=10)$ of cases and the bilateral temporal fractures results in 14\% ( $\mathrm{n}=4)$ were similar to the findings of SARAIYA et al (1) and Plaza Maior et al (10).

The longitudinal fractures occurred in 70 to $80 \%$ the temporal fractures and transverses were around of 20\% (26-8). From 28 patients submitted to CT of temporal bones, in 20 patients the facture was viewed, being 64\% $(n=18)$ longitudinal and in $7 \%(\mathrm{n}=2)$ transverse, similar results to LeE et al (2), Ishman et al (6) and Holland et al (8), in which longitudinal fracture was more frequent.

In patients with traumatic brain injury who presented clinical signs of temporal bones, it is fundamental the radiological evaluation of temporal bones, absence of fracture in skull CT does not exclude it. With high resolution CT of temporal bones there is a detailing of fracture line and its extensions, preventing and treating precocious complications and information of surgical planning.

\section{CONCLUSION}

The temporal bone fracture is frequently associated to the severe traumatic brain injury, and computerized tomography of high resolution in temporal bones allow the fracture evaluation and its extensions, this way with the involvement of important structures such as ossicular chain, cochlea, vestibule, semicircular canals and facial nerve.

\section{BibliograpHICAL ReFERENCES}

1. Saraiya PV, Aygun N. Temporal bone fractures. Emerg Radiol. 2009, 16(4):255-65.

2. Lee HJ, Lum C, Means K, Chandraseklar S, Brown L, Holodny A. Temporal bone fractures and complications:correlation between high-resolution computed tomography and audiography. Emerg Radiol. 1998, 5(1):08-12.

3. Waldron J, Hurley SEJ. Temporal bone fractures: a clinical diagnosis. Archives of Emergency Medicine. 1988, 5:14650.

4. Marques MPC. Trauma de osso temporal. Brazilian Journal of Otorhinolaryngology, 1999, 65(6):519-2.

5. Brodie HÁ, Thompson TC. Management of complications from 820 temporal bone fractures. The American Journal of Otology. 1997, 18(2):188-97. 
6. Ishman SL, Friedland DR. Temporal bone fractures: Traditional Classification and Clinical Relevance. Laryngoscope. 2004, 114:1734-41.

7. Johnson DW, Hasso AN, Stewart III CE, Thompson JR, Hinshaw Jr DB. Radiology. 1984, 151(2):411-15.

8. Holland BA, Zawadzki MB. High-resolution CT of temporal bone trauma. AJNR. 1984, 143:391-95.
9. Little SC, Kesser BW. Radiographic classification of temporal bone fractures:clinical predictability using a new system. Arch Otolaryngol Head Neck Surg. 2006, 132(12):01-08.

10. Plaza Mayor DG, Pérez Martinez C, Martinez San Millán J, Denia Lafuente A. Temporal bone fracture: review of 40 cases ( 44 traumatic injuries). An Otorrinolaringol Ibero Am. 1998, 25(6):531-46. 